\title{
The Role of Smooth Muscle Cells in Vessel Wall Pathophysiology and Reconstruction Using Bioactive Synthetic Polymers
}

\author{
M. PAŘíZEK ${ }^{1}$, K. NOVOTNÁ ${ }^{1}$, L. BAČÁKOVÁ ${ }^{1,2}$ \\ ${ }^{1}$ Department of Growth and Differentiation of Cell Populations and ${ }^{2}$ Center for Cardiovascular \\ Research, Institute of Physiology, Academy of Sciences of the Czech Republic, Prague, Czech \\ Republic
}

Received May 28, 2010

Accepted September 10, 2010

On-line March 14, 2011

\section{Summary}

This review summarizes recent trends in the construction of bioartificial vascular replacements, i.e. hybrid grafts containing synthetic polymeric scaffolds and cells. In these advanced replacements, vascular smooth muscle cells (VSMC) should be considered as a physiological component, although it is known that activation of the migration and proliferation of VSMC plays an important role in the onset and development of vascular diseases, and also in restenosis of currently used vascular grafts. Therefore, in novel bioartificial vascular grafts, VSMCs should be kept in quiescent mature contractile phenotype. This can be achieved by (1) appropriate physical and chemical properties of the material, such as its chemical composition, polarity, wettability, surface roughness and topography, electrical charge and conductivity, functionalization with biomolecules and mechanical properties, (2) appropriate cell culture conditions, such as composition of cell culture media and dynamic load, namely cyclic strain, and (3) the presence of a confluent, mature, semipermeable, non-thrombogenic and non-immunogenic endothelial cell (EC) barrier, covering the luminal surface of the graft and separating the VSMCs from the blood. Both VSMCs and ECs can also be differentiated from stem and progenitor cells of various sources. In the case of degradable scaffolds, the material will gradually be removed by the cells and will be replaced by their own new extracellular matrix. Thus, the material component in advanced blood vessel substitutes acts as a temporary scaffold that promotes regeneration of the damaged vascular tissue.

\section{Key words}

Tissue engineering - Bioartificial vascular grafts - Polymer irradiation $\bullet$ Wettability $\bullet$ Nanostructure $\bullet$ Dynamic bioreactor

\section{Corresponding author}

L. Bačáková, Dept. of Growth and Differentiation of Cell Populations, Institute of Physiology, Academy of Sciences of the Czech Republic, Vídeňská 1083, 14220 Prague 4 - Krc, Czech Republic. Fax: +420 24106 2488. E-mail: lucy@biomed.cas.cz

\section{Introduction}

Aim of the review

This review article summarizes our 20-year experience in studying the role of vascular smooth muscle cells in physiology and pathophysiology of blood vessels, and also the interaction of these cells with materials developed for constructing bioartificial vascular replacements. The main mechanisms of blood vessel damage, especially those related to VSMC, are briefly explained, and then the review concentrates on current and future ways of replacing irreversibly damaged blood vessels. As bioartificial vascular grafts contain material and cellular components, both these components, i.e. synthetic polymeric materials (including their surface modifications) and potential cell sources are observed. Mechanisms of the cell-material interaction and methods for studying these processes are also analyzed.

\section{Blood vessel damage}

Cardiovascular diseases, such as atherosclerosis and hypertension, are often associated with irreversible damage of the vessel and loss of its function. These diseases are relatively widespread in our population, and 
are serious risk factors with a marked influence on length and quality of life. Vascular smooth muscle cells (VSMC) play an important role in the mechanism of atherosclerotic plaque formation and in vessel thickening during hypertension. These disorders are initiated through mechanical damage to the endothelial cell lining of blood vessels, evoked mainly by non-physiologically high blood pressure, and also through biochemical damage to the endothelial cell layer due to civilization stress (e.g., increased level of cholesterol or glucose, smoking, etc.). The permeability of the endothelial cell layer then increases, and molecules not occurring inside the vessel under physiological conditions penetrate inside it. These molecules include particularly the platelet-derived growth factor (PDGF), which is chemotactic and mitogenic for VSMCs. PDGF-like molecules can be produced by VSMCs by an autocrine manner under pathological conditions (Bačáková-Řerábková 1990). Other proteins present in the blood, such as albumin, fibronectin and vitronectin, can also permeate to the vessel wall and change the qualitative composition of the vascular extracellular matrix (ECM). Both endothelium and VSMCs respond to vessel wall damage by immune activation, manifested by synthesis of imunoglobulin and selectin adhesion molecules, such as intercellular adhesion molecule-1 (ICAM-1), vascular adhesion molecule-1 (VCAM-1) or endothelial-leukocyte adhesion molecule-1 (ELAM-1), and by the presence of these molecules on the cell surface (Bačáková et al. 2000a,b, 2002). These molecules act as receptors for cells of the immune system, such as leukocytes, lymphocytes, macrophages and mast cells. The role of mast cells in pathology of the vessel wall has often been underestimated, although it has been reported that in a pathologically changed vessel wall the ratio between mast cells and VSMC, i.e. the most numerous cell component of the vascular wall, can reach 1:5 (Rohatgi et al. 2009, Maxová et al. 2010). Inflammatory cells then penetrate into the vessel wall, release proteolytic enzymes, disrupt and oxidize the ECM, and thus activate migration and growth of VSMCs (Bačáková et al. 1997, 1999, 2002). In addition, the inflammatory cells produce cytokines, for example interleukins or tumor necrosis factors (TNF). Similarly to PDGF, these agents stimulate the VSMCs to change their phenotype from contractile to synthetic, which is referred to as phenotypic modulation (Hedin and Thyberg 1987, Campbell and Campbell 1995, Orr et al. 2009). This modulation is characterized particularly by loss of specific isoforms of contractile proteins, such as alpha-actin and SM1- and SM2-myosins, and accumulation of cell organelles involved in proteosynthesis, such as endoplasmic reticulum, ribosomes or Golgi complex (Fager et al. 1989, Suzuki et al. 2010). Phenotypically modulated VSMCs are prone to hyperplastic and hypertrophic cell growth, migration into the tunica intima, production of osteopontin, i.e. a calcium-binding glycoprotein (Orr et al. 2009). They thus markedly participate in remodeling the vessel wall and in the creation of atherosclerotic plaques. Atherosclerosis is treated conservatively by a specific low-fat diet, following a healthy life style and the use of medicines, e.g. statins. However, severely and irreversibly damaged vessels must be replaced with autologous or artificial substitutes (for a review, see Chlupáč et al. 2009).

\section{Bioartificial vascular substitutes}

In modern tissue engineering, perfect blood vessel replacements can be based either completely on biological material, i.e. extracellular matrix and cells (totally-engineered blood vessels; for a review, see Chlupáč et al. 2009), or can be characterized as bioartificial, i.e. consisting of synthetic scaffolds and cells. Optimal artificial scaffolds are constructed as a three-dimensional porous or fibrous tubular structure. The wall of this tubular scaffold is assigned for ingrowth of VSMCs, which will form a contractile multilayer, and also for ingrowth of nourishing capillaries (i.e., vasa vasorum) and nerve fibres. The luminal surface of the tubular construct is designed to be colonized by endothelial cells, which are expected to form a continuous, phenotypically mature, and thus semipermeable, non-imunnogenic and non-thrombogenic layer. This layer also helps to maintain the underlying VSMCs in quiescent contractile phenotype, e.g. by synthesis of sulfated and heparin-like glycosaminoglycans (Bačáková et al. 2000b, 2004, Filová et al. 2009a, Bačáková and Švorčík 2008).

An important characteristic of artificial scaffolds in advanced bioartificial vessel substitutes is that they are not only passively tolerated by cells (as was the case for earlier generations of vessel and other tissue replacements), but that they mimic functions of the natural ECM. This means that the synthetic material regulates the extent and the strength of cell adhesion, cell growth activity, cell differentiation and maturation to a desired phenotype. Resorbable materials (often synthetic polymers) have been considered as ideal substrates for scaffold fabrication, because these matrices can gradually 
be replaced by cells and their newly formed natural extracellular matrix. In other words, in the concept of advanced tissue engineering, synthetic materials do not act as permanent vascular substitutes, but as temporary supportive structures stimulating regeneration of a defective vessel (Bačáková et al. 2004, 2007, Bačáková and Švorčík 2008).

However, experiments in laboratory animals have shown that degradable synthetic polymers often have insufficient mechanical qualities (Greisler et al. 1991), which can lead to the formation of an aneurysm on the vascular replacements or a rupture of the replacement. Relatively fast degradation of the polymer and slow regeneration of new vascular tissue also contribute to the insufficiency of the mechanical properties of vascular replacements based on degradable polymers. Resorbable polymers often used in tissue engineering, such as polylactides, polyglycolides, polycaprolactones and their copolymers, usually degrade within weeks or months, whereas for human vessel reconstruction, especially for older people with other intercurrent diseases, the degradation time should rather be several years. Therefore, even in advanced tissue engineering approaches, there has been a certain "renaissance" of biostable polymers in vascular wall reconstruction, or semi-degradable materials containing both resorbable and biostable polymeric components have been considered for this purpose (Greisler et al. 1991, Xue and Greisler 2003).

Differentiated autologous endothelial and smooth muscle cells, isolated from the patient's subcutaneous veins before the planned surgery, have usually been considered for use as the cell component of blood vessel replacements. These cells can be further expanded under in vitro conditions and seeded on to synthetic scaffolds. After phenotypic maturation of the cells, which can achieved in a dynamic cultivation system, this construct can be implanted into the patient's organism. Ideally, it can be expected that the synthetic scaffold will gradually be resorbed and replaced by newly regenerated functional vascular tissue (Bačáková et al. 2003, 2004, 2007, Bačáková and Švorčík 2008). However, differentiated cells may be available in limited quantities, and their growth activity can also be low. For these cases, attempts have been made to differentiate vascular cells from stem or progenitor cells, e.g. those present in bone marrow, blood, fat tissue, or skeletal muscle satellite cells are used (for a review, see Chlupáč et al. 2009, Filová et al. 2009b, Suzuki et al. 2010). The desirable cell phenotype can be achieved by an appropriate composition of the culture medium, and also by the physicochemical properties and the bioactivity of the synthetic scaffolds.

\section{Currently used vascular substitutes}

The tissue engineering approaches mentioned above, although promising for the future, still remain rather on a theoretical level, i.e., they have been applied in experiments in vitro or on laboratory animals. Autologous vessels are still considered as vascular substitutes of the highest quality - a classic example is an aortocoronary bypass created from subcutaneous veins of the lower limbs or from a. thoracica interna. However, this approach also has some limits, such as the availability of an appropriate healthy vessel for creating the substitute. As mentioned above, in our civilized society there are considerable numbers of people, especially those of older age, who suffer from vascular diseases including atherosclerosis. In addition, even healthy vessels are usually available only in limited quantities (for a review, see Chlupáč et al. 2009). Other serious problems are the burden to the patient due to additional surgery, donor site morbidity, and in the case of implantation of a vein into an arterial position, also limited adaptation of the vein tissue to higher mechanic requirements. This maladaptation is often manifested by activated migration, proliferation and synthesis activity of smooth muscle cells, i.e. effects that, together with endothelial layer damage and thrombus formation, lead to restenosis and failure of autologous vessel substitutes. It is also possible to use allogenous or even xenogenous substitutes from healthy donor organisms, but this approach is associated with the risk of immune rejection of the implant, and also the risk of pathogen transmission (Kakikis et al. 2005).

In the case of damaged vessels larger than $6 \mathrm{~mm}$ in diameter, artificial substitutes created from routinely available synthetic polymers, such as polyethylene terephthalate (PET) or expanded polytetrafluoroethylene (ePTFE), are currently used in clinical practice. These substitutes have relatively good mechanical properties and are resistant to stress due to the bloodstream. However, their potential for long-term durability and physiological function in the patient's organism is limited (Xue and Geisler 2003). These replacements have physical and chemical properties that are less appropriate for colonization with cells. Firstly, they are hydrophobic. This is the main factor limiting cell adhesion and thus 
hampering the desired reconstruction of a continuous and mature endothelial cell layer, which is considered to be the best anti-thrombogenic surface. In large diameter vascular replacements, a missing endothelial cell layer is not a factor markedly limiting long-term patency, because quick blood flow prevents the adhesion of thrombocytes and other blood cells to the prosthesis (for a review, see Chlupáč et al. 2009). However, in small diameter vessel replacements, the blood flow is slower, and thus thrombocytes and other blood components, including the cells of the immune system, can be accumulated here, and this can lead to stenosis or total obliteration of the artificial vessel. After implantation of the prosthesis the patients are therefore reliant for the rest of their lives on anticoagulant treatment, which can have negative side effects on their organism (for a review, see Chlupáč et al. 2009). Thus, in the case of small-diameter vascular replacements, there is a particularly important need for bioartificial vascular prostheses with a mature continuous layer of anti-thrombogenic endothelium.

Reconstruction of the endothelial cell layer has been at the centre of interest in all innovations of polymeric vascular replacements, while VSMCs have usually been excluded from these replacements due to the risk of their excessive proliferation and vessel restenosis (Chlupáč et al. 2009). However, VSMCs are the most numerous cell types in the natural vessel wall, and a contractile layer of these cells is a physiological component of this wall. For this reason, the tunica media containing VSMCs should also be reconstructed in advanced vascular replacements. The character of the synthetic material in these replacements, and also the cell culture environment used for preparing the cell-material construct, should direct VSMCs from the synthetic phenotype, which is usual in conventional cell culture systems, to maturation towards quiescent contractile phenotype (Bačáková et al. 2004, Bačáková and Švorčík 2008, Chlupáč et al. 2009).

\section{Synthetic polymers for reconstructing blood vessels}

Polymers for clinically and experimentally used vascular replacements

The vascular replacements used in current clinical practice are based on polyethylene terephthalate (PET) or polytetrafluoroethylene (PTFE). Polyurethane has been applied for constructing hemodialysis access grafts (for a review, see Chlupáč et al. 2009). In the experimental field, biostable polymers, such as polypropylene and polyethylene (PE), and also degradable polymers, such as polylactides, polyglycolides, polycaprolactone and their copolymers, have been used for creating cell carriers or prostheses tested in vitro or in laboratory animals (Bačáková et al. 1996, 2001a, 2004, 2007, Chlupáč et al. 2009).

Our studies have usually focused on the interaction of vascular endothelial and smooth muscle cells with PET, PTFE or PE. PET, also known under the trade name Dacron, is a thermoplastic polymer belonging to the polyester group, developed by polycondensation, where the catalyst is phthalic acid. This polymer is hydrophobic (advancing water drop contact angle about 90; van Bilsen et al. 2008). For vascular replacement construction purposes it is used mostly in fibrous form (knitted or woven), mimicking the architecture of the natural vessel. This fibrous structure can serve as a scaffold for colonization with cells (endothelial cells on the luminal surface of the prosthesis and VSMCs inside its wall), and will allow a certain degree of transmural tissue ingrowth, such as capillaries and connective tissue. A disadvantage of this type of vascular prosthesis, particularly if knitted, is its permeability for blood, which has been prevented by impregnation with proteins such as albumin, collagen or gelatine (Marois et al. 1996; for a review, see Chlupáč et al. 2009). Glutaraldehyde or formaldehyde used for crosslinking these proteins may persist in the prosthesis and have cytotoxic effects (You et al. 2010, for a review, see Filová et al. 2009b). Therefore, in our studies, knitted PET prostheses have been impregnated with a copolymer poly(glycolide-Llactide) or with a terpolymer poly(glycolide-L-lactide( $\varepsilon$ caprolactone). This approach has not only reduced their permeability, but has also enhanced their attractiveness for endothelial cells by flattening the relatively rough inner surface and increasing its wettability. Cell colonization has further been supported by coating the luminal surface of PET prostheses with fibrin, laminin and collagen type I in combination with laminin, fibronectin or fibrin (Chlupáč et al. 2006, 2008).

PTFE is known under the trade names Teflon or Goretex. It is a thermoplastic fluorinated polymer with a high oxygen index (i.e., a parameter of the flammability of the material), which means that this material is relatively resistant to fire and high temperatures (Cullis and Hirschler 1983). From a clinical point of view, PTFE is a more biostable material than PET, i.e. it is less prone to deterioration in biological environments, and has low 
reactivity towards blood elements. For fabricating vascular prostheses, expanded PTFE is used, i.e. with a porous structure created by a special manufacture technology based on heating, stretching and extruding the material. The mechanical properties of PTFE are highly suitable for constructing vascular replacements (Guidoin et al. 1993). However, similarly to PET, PTFE in its unmodified state is also highly hydrophobic, and this is a limiting factor for cell adhesion and for potential construction of bioartificial vascular prostheses based on PTFE scaffolds (Heitz et al. 2003, Chlupáč et al. 2009).

Polyethylene (PE) has been used as a model material because of its good availability, low cost and relatively easy processing by methods commonly used for polymer surface modification. It is biostable and resistant to deterioration by water, frost and various chemicals. PE has been classified into several different categories based mostly on its density and branching. The most frequentlyused types of PE are ultra-high molecular weight polyethylene (UHMWPE), used as a component for total joint replacements and spine implants, low density polyethylene (LDPE, density $0.922 \mathrm{~g} / \mathrm{cm}^{3}$ ), and high density polyethylene (HDPE, density $0.951 \mathrm{~g} / \mathrm{cm}^{3}$ ) (Švorčík et al. 2006).

Concerning its physical and chemical properties, LDPE has a slightly lower water drop contact angle of $98^{\circ}$, while HDPE has a contact angle of $102^{\circ}$. This difference in the contact angles between LDPE and HDPE is relatively small; thus both polymers are considered to be highly hydrophobic. However the two polymers differ from each other more markedly in their structure. HDPE has linear chains, whereas LDPE is branched (Hameed and Hussain 2004, Ducháček 2006). These differences could explain, at least partly, the higher adhesion and growth of VSMCs on LDPE observed in our studies, although the cell colonization was relatively low on both types of PE. Similarly to PET and PTFE, PE in its pristine unmodified state is not optimal for scaffolds for vascular tissue engineering, due to its bioinertness (Švorčík et al. 1995, 2006, 2009, Bačáková et al. 2001a, Walachová et al. 2002, Kasálková et al. 2008, 2010, Pařízek et al. 2009).

\section{Polymer modification methodology}

Modifications are made to the polymers used in our studies in order to change their physical and chemical surface properties, such as polarity, wettability, chemical composition (presence of oxygen-containing chemical functional groups, free radicals, carbon content, etc.), surface roughness and topography. These characteristics of the polymer surface are the key factors controlling spontaneous adsorption of extracellular matrix (ECM) molecules from biological fluids such as culture medium or blood. These characteristics determine the type of adsorbed molecules - for example, vitronectin, fibronectin and collagen are adsorbed preferentially on wettable surfaces, while albumin is absorbed preferentially on hydrophobic surfaces. The quantity, geometrical conformation and flexibility of cell adhesionmediating molecules are also influenced by the physical and chemical properties of the material surface, and by the consequent availability of specific sites on ECM molecules for cell adhesion receptors, which direct the subsequent cell behavior, e.g. their adhesion, spreading, migration, proliferation, differentiation, viability and other cell functions (Bačáková et al. 2004, Bačáková and Švorčík 2008).

A range of physical and chemical modifications have been used to create a bioactive surface attractive for cell colonization. For example, in our earlier studies, polymers were irradiated with ultraviolet light (UV), ions or plasma irradiation, and some of them were subsequently grafted with various biomolecules or nanoparticles attached to newly-developed binding sites on the activated polymer.

UV light irradiation is a relatively simple and easily available method for changing the physical and chemical surface properties of synthetic polymers in order to enhance their bioactivity. In our studies performed in collaboration with the Department of Applied Physics, Institute of Experimental Physics, Johannes-Kepler-University, Linz, UV light was generated using a Heraeus-Noblelight $\mathrm{Xe}_{2}$ lamp (Hanau, Germany; centre wavelength of $172 \mathrm{~nm}$, spectral bandwidth about $16 \mathrm{~nm}$, intensity about $22 \mathrm{~mW} / \mathrm{cm}^{2}$ ). The exposure time ranged from 5 to $30 \mathrm{~min}$ (Heitz et al. 2003, Mikulíková et al. 2005, Bačáková and Švorčík 2008). In our earlier studies, this method was used to modify the surfaces of PTFE (Heitz et al. 2003, Mikulíková et al. 2005) or PET foils (Kubová et al. 2007). Polymer modification by UV light has usually been performed homogeneously on the entire polymer surface. However, it is also possible to achieve irradiated micro-domains of various sizes, shapes, distances and distributions on the polymer surface in order to guide regionally-selective cell adhesion and growth. For this purpose, we used metallic (e.g. nickel) contact masks with gaps ranging in diameter from several micrometres 

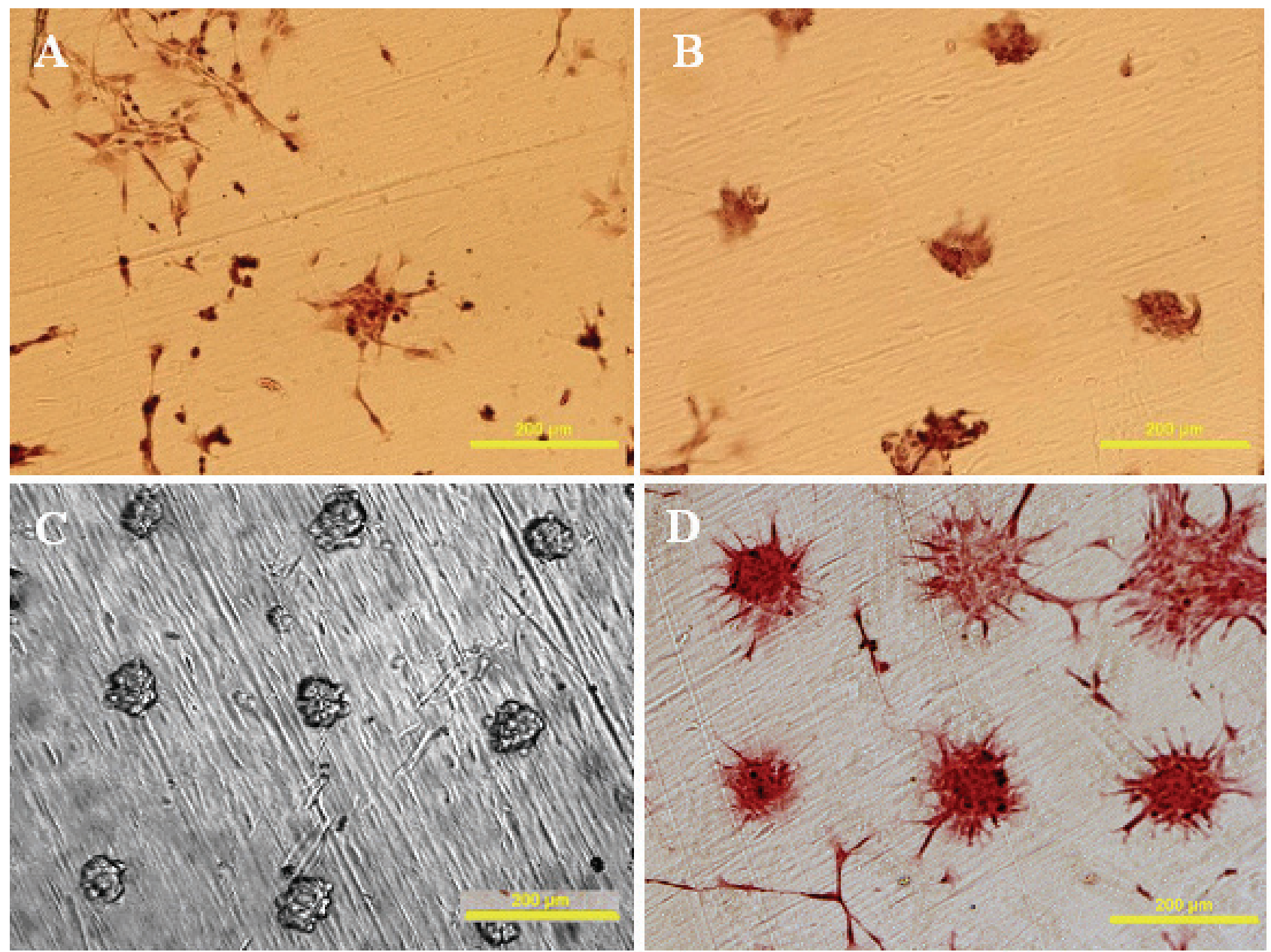

Fig. 1. Effects of time of exposure to UV light, cell type, and time of cultivation on cell adhesion to UV-irradiated domains created on PTFE through a nickel mask with round openings (diameter $100 \mu \mathrm{m}$, center-to-center distance $300 \mu \mathrm{m}$ ) in an ammonia atmosphere. A, B: Rat aortic smooth muscle cells on day 1 after seeding on PTFE irradiated for 10 min and 20 min, respectively. C, D: Human umbilical vein endothelial EA.hy926 cells and rat aortic smooth muscle cells, respectively, on day 3 after seeding on PTFE irradiated by UV light for 20 min. B, D: Rat aortic smooth muscle cells on PTFE irradiated for 20 min on day 1 and day 3 after seeding, respectively. The cells were stained with hematoxylin-eosin and photographed under an Olympus IX 50 microscope using a DP 70 digital camera, except in the case of $B$, where the cells are native and are photographed using a phase-contrast microscope (Zeiss, Germany) with a CCD-camera (PCO-Sensicam, Kelheim, Germany). Bar $=200 \mu \mathrm{m}$.

to hundreds of micrometres. The spacing between the gaps was usually hundreds of micrometres or even millimetres, in order to avoid possible bridging of the unexposed regions by cells, especially by VSMCs. Compared to other cell types, such as the vascular endothelial cells or human embryonic kidney (HEK) cells also used in our studies, VSMCs were more active in migration and growth, and thus also in overlapping the irradiated domains and spanning the unmodified polymer regions. The selectivity of cell adhesion on the irradiated domains was also influenced by the time of exposure to UV light, cell seeding density and the time of cell cultivation (Mikulíková et al. 2005, Pařízek et al. 2009, Bačáková et al. 2009; Fig. 1).

As mentioned above, the purpose of irradiating synthetic polymers is to convert their surfaces, which are rather bioinert in their pristine unmodified state, to bioactive surfaces promoting cell colonization. UV light irradiation induces degradation of polymer chains and the release of some atoms, namely hydrogen or fluorine in PTFE, from the polymer, and the creation of radicals. These radicals react with air oxygen, leading to the formation of oxygen-containing functional chemical groups on the polymer surface (Heitz et al. 2003, Mikulíková et al. 2005, Bačáková and Švorčík 2008). Afterwards these groups enhance the polymer polarity and wettability, and in this way they have a favorable influence on the adsorption of cell adhesion-mediating ECM molecules. These molecules, including particularly fibronectin, vitronectin, collagen or laminin, are present in biological fluids such as standard serum-supplemented cell culture media, blood or extracellular fluid, and are 
also synthesized and deposited by cells colonizing the polymer (for a review, see Bačáková et al. 2001a, 2004, Bačáková and Švorčík 2008).

Changes in the polymers induced by UV irradiation can be further intensified by irradiation in reactive atmospheres, such as $\mathrm{NH}_{3}$ (Heitz et al. 2003, Mikulíková et al. 2005) or acetylene (Kubová et al. 2007). In our experiments, the most positive effect on cell adhesion was observed when the polymers were irradiated in an $\mathrm{NH}_{3}$ atmosphere. When PTFE was irradiated with UV light in this atmosphere, fluorine atoms were substituted with $\mathrm{C}-\mathrm{H}, \mathrm{C}=\mathrm{O}$ and particularly $\mathrm{C}-\mathrm{NH}_{2}$ groups. It is well known that amino groups not only enhance the wettability of a material but also provide its positive charge. This has favorable effects on the adsorption of cell adhesion mediating proteins (Heitz et al. 2003, Mikulíková et al. 2005, Liu et al. 2007; for a review, see Bačáková and Švorčík 2008).

Ion irradiation of polymers, also known as ion implantation, is based on similar principles as UV light irradiation. This method was originally developed for technical purposes, for example for incorporating metal ions into materials designed for electronics (Fink et al. 2004, Macková et al. 2006, Švorčík and Hnatowicz 2007). Using this method, various materials can also be enriched with various ions for biological purposes; for example, calcium can be implanted into materials for bone replacements (Nayab et al. 2007). In our studies, we have focused on modifying synthetic polymers, such as polyethylene, polystyrene and polypropylene, with gas ions considered as biocompatible, namely oxygen and carbon ions, halogens, such as fluorine, or inert gases, such as argon (Švorčík et al. 1993, 1995, Bačáková et al. 1996, 2000a,b, 2001a, Walachová et al. 2002, Švorčík and Hnatowicz 2007). During ion bombardment of the polymer, these ions are not retained in the polymer structure (or only minimally, usually below the limit detectable by available methods; Bačáková et al. 2000a, 2001a). However, the ions cause changes in the polymer leading to its oxidation and subsequent enhancement of its polarity and wettability. As in the case of UV light irradiation, the polymer chains are degraded, various atoms are released, radicals are formed and they react with oxygen. These processes take place already in the implantation chamber, where the vacuum is not absolute (the pressure of the residual air is about $10^{-4} \mathrm{~Pa}$ ), and continue after exposition of the irradiated material to the air atmosphere. Chemical functional groups containing oxygen (i.e., carbonyl, carboxyl, hydroxyl, ether or ester groups) are exposed on the polymer surface, enhance its polarity and wettability and promote the adsorption of cell adhesion-mediating molecules in appropriate geometrical conformations, which enable the specific amino acid sequences in the molecules to be reached by cell adhesion receptors (Bačáková et al. 2000a,b, 2001a).

As for the energy and dosage of ions, the surface of the samples used in our experiments was bombarded by ions of energies from 15 to $150 \mathrm{keV}$ and of doses from $10^{12}$ to $10^{15}$ ions $/ \mathrm{cm}^{2}$. Higher ion energies and doses in this range (i.e., $150 \mathrm{keV}$ combined with $5 \times 10^{14}$ or $10^{15}$ ions $/ \mathrm{cm}^{2}$ ) resulted in an interesting effect, referred to as "relative carbonization" of the polymer. This means that during intensive irradiation of the polymer, the release of non-carbon atoms from the polymer prevailed over binding new atoms from the ambient atmosphere. As a result, the content of non-carbon atoms in the polymer decreased markedly and carbon relatively outweighed the other atoms, although its absolute content remained unchanged. In addition, conjugated double bonds arose between carbon atoms, and the polymer became electrically conductive - its electrical resistivity was able to decrease by as many as 15 orders of magnitude. This newly established electrical conductivity also significantly supported colonization of the polymer with cells (Švorčík et al. 1995, Bačáková et al. 1996, 2000a,b, 2001a). It is known that the electrical conductivity of other types of materials, too, enhances cell adhesion and growth, even without active electrical stimulation of the cells (Jeong et al. 2008, Mihardja et al. 2008, Bettinger et al. 2009).

Similarly as in the case of UV light irradiation, ion irradiation can also be performed through contact metal masks in order to create microdomains adhesive for cells (Pař́zek et al. 2009).

Plasma irradiation of polymers is another important technology for changing the physicochemical properties of the polymer surface in a similar way as by the use of UV light irradiation or ion irradiation. In our studies we used a Balzer SCD 050 device, where the polymers, mainly polyethylene, were irradiated with $\mathrm{Ar}^{+}$ plasma for various time intervals ranging from tens to hundreds of seconds (usually 50-400 s). The $\mathrm{Ar}^{+}$plasma discharge activated the polymer surface by creating reactive radicals, oxygen-containing chemical functional groups and groups with double bonds (Kasálková et al. 2008, 2010, Švorčík and Hnatowicz 2008). These active sites were grafted with various biologically active molecules, such as amino acids (glycine, arginine), 
proteins (albumin, fibronectin), other synthetic polymers (polyethylene glycol), and even carbon or gold (Pařízek et al. 2009, Švorčík et al. 2009, Kasálková et al. 2010). These elements can be grafted to the activated polymer surface in the form of nanoparticles from a colloidal suspension of these elements in water (Pařízek et al. 2009, Švorčík et al. 2009). The nanostructure of the polymer, created by partial polymer degradation during irradiation and further enhanced by the attachment of nanoparticles, is supportive for cell adhesion by a mechanism synergistic with that on moderately wettable surfaces, i.e. adsorption of cell adhesion-mediating proteins in an appropriate geometrical conformation for binding them with cell adhesion receptors (Miller et al. 2007).

\section{Mechanism of cell-material interaction}

As mentioned above, the cells adhere to conventional biomaterials (i.e. those not endowed with ligands for cell adhesion receptors, e.g. RGD-containing oligopeptides) through ECM proteins, spontaneously adsorbed on the material surface exposed to biological environments. Under in vivo conditions, these proteins are adsorbed from body fluids, and under in vitro conditions they are adsorbed from the serum in the culture medium, and also after synthesis and secretion by cells colonizing the material.

The cells can also be attached to the material surface without adsorbed proteins, i.e. through weak chemical bonds between molecules of the cell membrane and the material surface. However, these bonds are nonspecific, i.e. not mediated by cell adhesion receptors, and thus they cannot transfer adequate signals into the cells ensuring their viability, growth, differentiation and other specific functions (for a review, see Bačáková et al. 2004, Bačáková and Švorčík 2008).

\section{Proteins mediating cell-material adhesion}

ECM proteins that which mediate the cellmaterial adhesion and markedly influence the subsequent cell behavior, such as cell spreading and shape, migration, proliferation, metabolic activity, viability, differentiation and phenotypic maturation, include particularly collagen, elastin, fibronectin, vitronectin and laminin. Most of these proteins are important components of vascular ECM in vivo, and therefore they play a significant role in blood vessel reconstruction and regeneration.
Collagen is a widespread protein in mammalian tissues, where it represents $25-30 \%$ of all proteins in mammalian organisms. Its molecule consists of three polypeptide strands (called alpha chains), each possessing the conformation of a left-handed helix. These three lefthanded helices are twisted together into a right-handed coil, also referred to as a triple helix or a "super helix", which is a cooperative quaternary structure stabilized by numerous hydrogen bonds. The collagen molecule, i.e. tropocollagen, is approximately $300 \mathrm{~nm}$ in length and $1.5 \mathrm{~nm}$ in diameter, and is a subunit of larger collagen aggregates, namely fibrils. The fibrils are interconnected through covalent bonds, which provide large mechanical stability to the whole collagen network (Abraham et al. 2008). Nowadays, 29 various types of collagen have been described. The most common is the type I, which represents $90 \%$ of collagen in a living organism and is contained mainly in the epidermis, ligaments, bones and teeth, and it is also an important component of the vascular ECM. Type II occurs in cartilages. Type III is collagen of embryonic development, and it is later replaced by collagen I. However, its content increases in the vascular wall under pathological conditions, which can be due to a dedifferentiated synthetic phenotype of VSMC, which is in some aspects similar to the embryonic and fetal VSMC phenotype (Bačáková et al. 1997, 2002). Type IV occurs together with laminin in cell basal laminae, and together with laminin it maintains the VSMCs in the differentiated contractile phenotype (Roy et al. 2002). VSMCs bind collagen through $\beta_{1}$-integrin adhesion molecules, especially through $\alpha_{1} \beta_{1}, \alpha_{2} \beta_{1}, \alpha_{3} \beta_{1}$ integrins, which are referred to as "collagen receptors" (Glukhova and Koteliansky 1995).

Elastin is defined as an insoluble scleroprotein, and is the main component of elastic fibers in animal tissues (ligaments, bronchi, lungs and vessel wall tissues). It contains a large amount of glycine, proline and aliphatic amino acids (alanine, valine, leucine and isoleucine), and also relatively numerous basic lysine residues. As for the vascular wall, high quantities of elastin occur in large vessels near the heart, such as thoracic aorta or carotid arteries. VSMCs are attached to elastin through a non-integrin adhesion receptor, which recognizes the amino acid sequence VAPG (Val-Ala-ProGly) in the elastin molecule (Gobin and West 2003). As elastin maintains VSMCs in a quiescent differentiated contractile phase (Karnik et al. 2003), recombinant elastin-like proteins with VAPG sequences are considered to be suitable for constructing bioartificial 
blood vessel replacements (Bandiera et al. 2005).

Fibronectin belongs to the family of dimeric glycoproteins (molecular weight about $600 \mathrm{kDa}$ ). It has binding sites for other ECM molecules, such as collagen, heparan sulfate proteoglycans and also fibrin, a provisional matrix molecule taking part in wound healing, including repairs to vascular damage. Fibronectin can connect many ECM molecules into a continuous network. It is also an important component of blood serum, which is commonly used as a supplement for the cell culture media (Bačáková and Švorčík 2008). The cells adhere to fibronectin through integrin receptors, particularly integrin $\alpha_{5} \beta_{1}$, referred to as a "fibronectin receptor". Another important receptor for fibronectin on the cell membrane is the $\alpha_{v} \beta_{3}$ integrin. Both $\alpha_{5} \beta_{1}$ and $\alpha_{v} \beta_{3}$ integrins bind fibronectin through the RGD (Arg-GlyAsp) sequence in its molecule (Glukhova and Koteliansky 1995). Fibronectin can alternatively be spliced in three regions, namely extradomains EIIIA, EIIIB, and a variable segment $\mathrm{V}$, potentially giving rise to functionally distinct variants of the molecule (Barnes et al. 1995). When differentiated mature VSMCs, freshly isolated from the rat aorta, were seeded on fibronectin substrates, fibronectin induced their phenotypic modulation to synthetic phenotype, and, in the presence of growth factors, also their migration and proliferation (Roy et al. 2002). Moreover, in the presence of a special osteogenic cell culture medium, fibronectin induced osteogenic differentiation of VSMCs, manifested by expression of osteocalcin, i.e. a calcium-binding ECM glycoprotein, activity of alkaline phosphatase and tissue calcification (Ding et al. 2006).

Similar effects were also observed in the presence of serum fibronectin in the culture medium (Hedin and Thyberg 1987). Also in experiments performed in vivo on mice with partial ligation of the carotid arteries, infusion of pUR4, i.e. a fibronectin polymerization inhibitor, reduced carotid intima, media and adventitial thickening, leukocyte infiltration into the vessel wall, ICAM-1 and VCAM-1 levels, cell proliferation and VSMC phenotypic modulation (Chiang et al. 2009). On the other hand, in non-differentiated progenitor cells, and also in other cell types than VSMC, such as mesangial cells, fibronectin is capable of inducing differentiation towards VSMC phenotype, manifested by synthesis of alpha-actin (Costa-Silva et al. 2009).

Vitronectin is a $75 \mathrm{kDa}$ glycoprotein consisting of 459 amino acid residues. It is plasmatic glycoprotein circulating in blood in a concentration of $200-400 \mathrm{mg} / \mathrm{ml}$, present in the serum supplement of the cell culture medium and in the extracellular matrix. It is one of the principal glycoproteins enabling cell adhesion and spreading, and the main ligand for vitronectin cell receptors, such as $\alpha_{v} \beta_{3}, \alpha_{\mathrm{II}} \beta_{3}, \alpha_{v} \beta_{1}, \alpha_{v} \beta_{5}$. Other molecules bound by vitronectin are heparin and collagen. In cell cultures, vitronectin induces migration, proliferation and synthetic phenotype of VSMCs (Dufourcq et al. 2002).

Laminins are high molecular multidomain heterotrimer proteins ( $850 \mathrm{kDa})$, composed of $\alpha-, \beta$ - and $\gamma$-chains, and these chains occur in five, three and three genetic variants, respectively. Laminins are major proteins of the cellular basal lamina. In the vascular wall, laminin together collagen IV, elastin and sulfated and heparin-like glycosaminoglycans maintains VSMCs in a quiescent differentiated contractile state. Sixteen laminin isoforms have been described in mammals. The cellular receptors for laminin are integrins $\alpha_{1} \beta_{1}, \alpha_{2} \beta_{1}, \alpha_{6} \beta_{1}, \alpha_{7} \beta_{1}$, $\alpha_{9} \beta_{1} \quad$ (Bačáková-Řeřábková 1990, Glukhova and Koteliansky 1995, Roy et al. 2002, Suzuki et al. 2010).

In addition to proteins and glycoproteins, cells can also adhere to the growth surface through ECM molecules based mainly on saccharides, for example proteoglycans. These molecules are formed by a polypeptide chain, to which glycosaminoglycans (i.e., polysaccharides containing glucosamin) are bound. Polysaccharide chains are hydrophilic and bind a relatively high amount of water, i.e., they form gels (Nečas et al. 2000). A cell binds proteoglycans through non-integrin adhesion receptors, which also are saccharide-based molecules (for a review, see Bačáková et al. 2004, Bačáková and Švorčík 2008).

\section{Mechanism of ECM-material and ECM-cell binding}

Binding between cells and ECM molecules through adhesion receptors, especially binding between protein molecules and integrins, has been intensively investigated in many studies (for a review, see Bačáková et al. 2004, Bačáková and Švorčík 2008). However, less is known about bonding between ECM molecules, spontaneously adsorbed on an artificial material, and the material. It is usually the result of weak chemical bonding, such as hydrogen bonds, van der Waals forces, polar or electrostatic interactions. Protein molecules are more weakly bound to the material surface with increased hydrophilicity. The hydrophilicity of the material provides flexibility of these molecules, easier remodeling and availability of specific bioactive sites (e.g., adhesion oligopeptides) in these molecules for cell adhesion 
receptors. On the other hand, extremely hydrophilic surfaces inhibit stable adsorption of proteins, and thus adhesion of cells. Cell adhesion is therefore highest on moderately hydrophilic surfaces, i.e. usually surfaces with a water drop contact angle between 50-80 . Highly hydrophobic surfaces (contact angle more than $100^{\circ}$ ) adsorb ECM molecules in rigid and denaturated forms, which hamper or even disable the binding of cell adhesion receptors to the ECM molecules (for a review, see Bačáková et al. 2004, 2007, Bačáková and Švorčík 2008). On the other hand, when the ECM molecules were bound covalently in a controllable manner to hydrophobic surfaces, they resembled the physiological ECM and promoted cell adhesion (Brynda et al. 2005, Filová et al. 2009a).

As indicated above, the cells do not bind the entire protein or glycoprotein macromolecules, but only their specific amino acid sequences, which are typical for a specific protein or which are preferred by a certain cell type for binding. For example, typical sequences are YIGSR and IKVAV for laminin, REDV for fibronectin, DGEA for collagen, VAPG for elastin, and RGD and KQAGDV for both vitronectin and fibronectin sequences (for a review, see Bačáková et al. 2004, Bačáková and Švorčík 2008).

Concerning the amino acid sequences preferred by certain cell types, KQAGDV and VAPG sequences are preferred for adhesion by vascular smooth muscle cells, REDV by endothelial cells, KRSR are bound by osteoblasts, and YIGSR and IKVAV by nerve cells. Sequences like RGD or DGEA have no significant preference for specific cell types (Nečas et al. 2000, Bačáková et al. 2003, 2004, 2007, Bačáková and Švorčík 2008).

Cells bind the amino acid sequences of adsorbed proteins with adhesion receptors located on the cell membrane. The most intensively investigated and systematized type of adhesion receptors are integrins. Integrins are heterodimeric transmembrane glycoproteins with binding sites for ECM molecules located on their extracellular part. The intracellular part of integrins is associated with several structural and signaling proteins, such as paxillin, talin, vinculin and focal adhesion kinase. These proteins further communicate with the actin cytoskeleton, which crosses the entire cell and is also connected to the nuclear membrane. The sub-membrane actin cytoskeleton is thus structurally associated with the exoskeleton (in our case represented by the ECMmaterial complex), through integrins. This feature has been referred to as the transmembrane skeleton. This skeleton limits the fluidity of the proteins, determines the functional differentiation of specific parts of the cell membrane, for example establishing the apical and basal part of the membrane in epithelial cells, and thus their polarity. The transmembrane character of the cell membrane skeleton enables exogenous factors to interact with the interior of the cell, and also enables signaling in the inside-out direction. In this way, the signal provided by the artificial cell carrier can influence the gene expression and proteosynthesis in the adhering cells, and thus their behavior, such as spreading, migration, viability or death, switching between proliferation and differentiation, and also remodeling or degradation of the artificial growth support by cells (Nečas et al. 2000, Bačáková et al. 2004, 2007, Ochsenhirt 2006, Bačáková and Švorčík 2008).

\section{Methods for studying the cell-material interaction}

\section{Conditions of cell cultivation on artificial materials}

Our earlier studies focused mainly on monitoring the interaction between cells and materials in vitro. For this purpose, anchorage-dependent cells were used, i.e. cells whose survival and functions are dependent on specific receptor-mediated adhesion to a growth substrate. This substrate has to be stable in order to resist the tractional forces produced by the actin cytoskeleton during cell spreading. If the material is too weak, it does not allow the assembly of the actin cytoskeleton and focal adhesions, i.e. domains on the cell membrane where integrins cluster together and communicate with structural and signal proteins of the cell membrane and cytoplasm, such as paxillin, talin, vinculin, focal adhesion kinase and the actin cytoskeleton. The creation, maturation and function of focal adhesions is necessary for future viability, division and phenotypic maturation of all types of anchoragedependent cells. In other words, not only wettability or surface topography, i.e. commonly studied properties of a material, but also its mechanical properties play a decisive role in the cell-material interaction (Engler et al. 2004, Bačáková et al. 2004, Zaidel-Bar et al. 2007, Bačáková and Švorčík 2008).

The classical static cell culture system has usually been applied for studying cell-material interaction in vitro. In this system, the material samples, usually of planar "two-dimensional" character, are inserted into 
plastic culture dishes, seeded with cells, immersed in a culture medium and incubated at $37{ }^{\circ} \mathrm{C}$ in a humidified air atmosphere with $5 \% \mathrm{CO}_{2}$. For standard cultivation of cells, the medium is supplemented with $5-20 \%$ blood serum (usually fetal bovine serum), which contains growth factors (e.g., platelet-derived growth factor), proteins mediating cell adhesion (vitronectin, fibronectin) and also albumin, which is non-adhesive for cells. In special cases, a serum-free medium can be used, for example a medium supplemented with essential growth factors, hormones etc., in order to evaluate the ability of the cells to bind the material without the cell adhesionmediating proteins adsorbed from the serum. This approach is used particularly when the material surface is functionalized with oligopeptidic and other ligands for cell adhesion receptors (Bačáková et al. 2007). Another important application of serum-free media is for inducing cell differentiation, particularly VSMC. For example, differentiation of VSMCs can be induced using SMC DSTIM $^{\text {TM }}$ Differentiation Medium, supplemented with insulin, transferrin, selenous acid, linoleic acid and bovine serum albumin. This medium is optimized for use with BD BioCoat ${ }^{\mathrm{TM}}$ Growth Factor Reduced Matrigel (BD Biosciences), i.e. a mixture of ECM molecules imitating the basal lamina and containing predominantly laminin (www.bdbiosciences.com).

Disadvantages of the static cultivation system are a relatively low level of oxygen and nutrition delivery to the cells and slow waste removal, which has a negative influence especially on cells colonizing the inside of three-dimensionally constructed materials. In addition, there is usually no mechanical stimulation of the cells, which is necessary for their proper phenotypic maturation. On the other hand, the cells are less subjected to rinsing out from the material surface, and they have enough time to adhere and grow on the surface of the investigated sample. Static cultivation is often used prior to dynamic cultivation in order to achieve adhesion of cells in high initial numbers (near confluence) and through a large cell spreading area, which is desirable particularly in vascular smooth muscle cells. Numerous and large cell-cell and cell-material contacts shorten the proliferative phase and accelerate entry into the differentiation program (Bačáková et al. 2004, Bačáková and Švorčík 2008).

For more sophisticated studies requiring better imitation of the conditions in the living organism, the use of dynamic cultivation systems is more convenient. These systems are also more appropriate for testing and finishing new bioartificial tissue or organ replacements developed by tissue engineering methods. Dynamic perfusion systems, which enable the application of laminar shear stress and cyclic strain stress to the cellmaterial construct, are needed for constructing bioartificial vascular replacements. Laminar shear stress is necessary for phenotypic maturation of endothelial cells, manifested by the development of a confluent, semipermeable, non-immunogenic and non-thrombogenic endothelial cell monolayer (Wang et al. 2005). Strain stress is necessary for the development of contractile phenotype in VSMCs (Shimizu et al. 2008).

Perfusion bioreactors for the creation of bioartificial vascular grafts usually consist of a tubular cultivation chamber for inserting a tubular material construct, a reservoir of cell culture medium, a pump generating flow of the medium and pulsation in a controllable manner, and tubing that enables the medium to flow through the cultivation chamber (Fig. 2A-C). Prior to exposure to the flow of the medium, the cells are seeded on the tubular construct fixed in the tube chamber slowly rotating along its long axis (about 3-5 rounds per hour). The perfusion system can also be adapted for porous sponge-like or fibrous 3D scaffolds (e.g., for bone tissue engineering) by changing the tubular cultivation chamber for a perfusion chamber (Fig. 2 D, E). Perfusion of $3 \mathrm{D}$ cell-material constructs with the culture medium can be also achieved in a bioreactor with a rotating cultivation chamber (Fig. 2F). These systems ensure better accessibility of fresh culture medium to the cells, waste removal and appropriate mechanical stimulation of the cells. Some systems also enable continuous saturation of the culture medium with oxygen. Dynamic cultivation systems accelerate cell differentiation, phenotypic maturation and induce cell functions typical for a certain cell type (Bačáková and Švorčík 2008).

\section{Cell types used for studying cell-material interaction}

Testing the biocompatibility and bioactivity of an artificial material usually starts with the use of commercially available cell lines. These cells provide relatively well-growing and easily cultivable cell populations (for example, the life expectancy can reach several tens or even hundreds of population doublings). These cell populations are relatively homogeneous, with stable phenotypic characteristics, and are able to give reproducible results. Despite long-term cultivation and repeated passaging, many cell lines retained important markers of a given cell phenotype. For example, the 

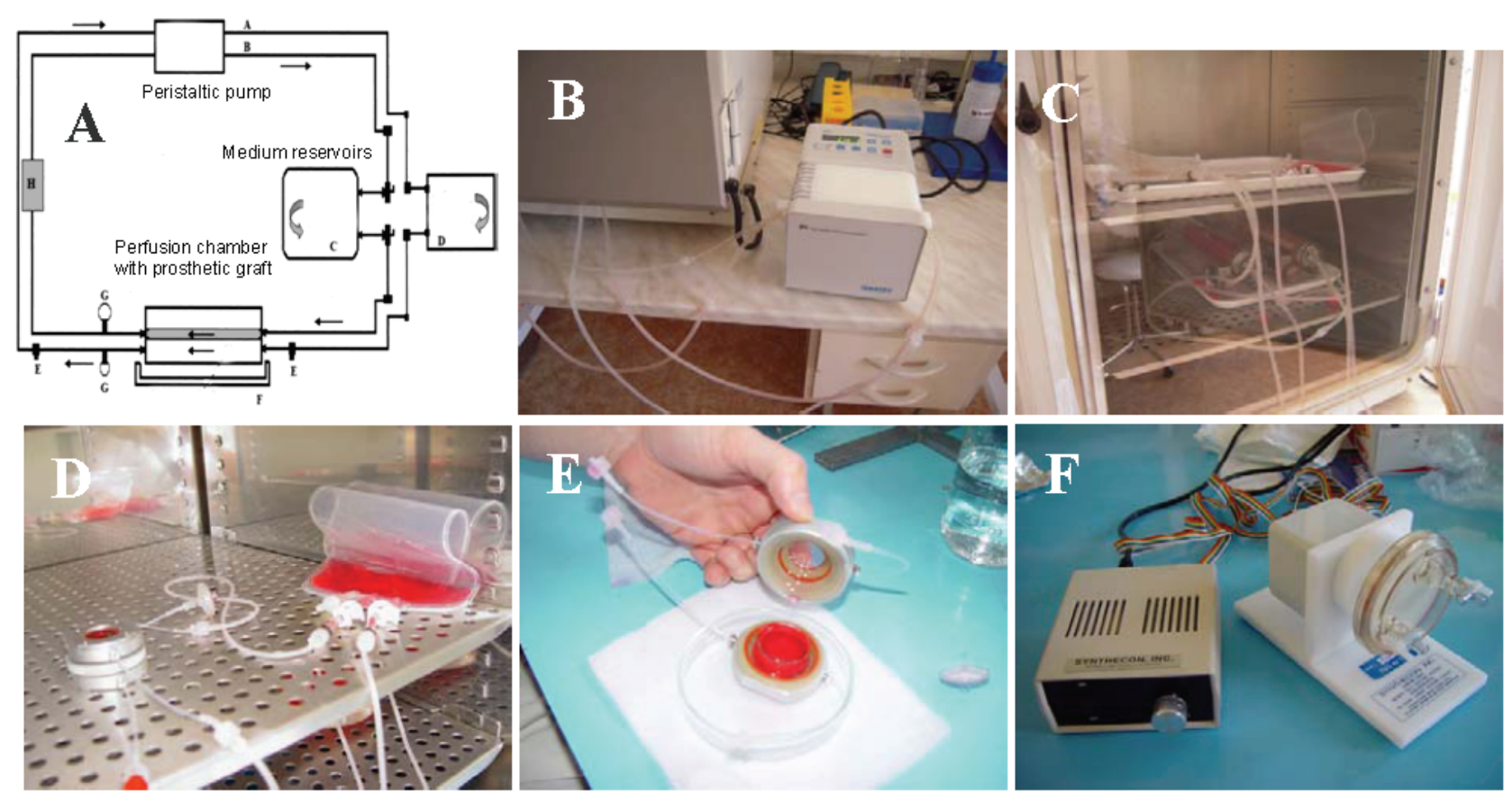

Fig. 2. A-E: Dynamic perfusion cell culture system (Provitro $\mathrm{GmbH}$, Berlin, Germany). A: Scheme of the system with a peristaltic pump (above), medium reservoirs (centre) and a perfusion chamber with a prosthetic graft (below). B: Peristaltic pump with silicon tubing conducting the culture medium into a cell incubator. C: The interior of the cell incubator with medium reservoirs (upper shelf) and perfusion chambers with endothelializing vascular prostheses (lower shelf). D, E: Perfusion chamber for 3D porous or fibrous scaffolds. F: Dynamic rotary cell culture system (Cellon, Synthecon, Luxembourg).

VSMC line A7r5 derived from rat aorta (ATCC CRL1444, Rockville, MD, U.S.A.), used in our earlier study for an investigation of the effects of material compliance on cell adhesion and spreading (Engler et al. 2004), retained the main VSMC differentiation markers, such as SM-alpha actin, SM-calponin and SM-myosins (Graves and Yablonka-Reuveni 2000). Bovine pulmonary artery endothelial cells of the line CPAE, used in our earlier studies on ion-implanted polymers, micropatterned surfaces created by plasma polymerization of acrylic acid and octadiene and fibrin nanostructures for potential construction of a bioarteficial vascular wall, maintain a "cobblestone-like" morphology of the cells and can form a semipermeable confluent monolayer expressing the von Willebrand factor (vWf) and angiotensin-converting enzyme, characteristic for normal endothelium in situ (Bačáková et al. 2000b, Filová et al. 2009a,c). Lines established from human umbilical vein endothelial cells (HUVEC) provide a good model of physiological endothelial cells. For example, the line HUVEC-CS (ATCC CRL-2873) exhibits positive acetylated lowdensity lipoprotein (AcLDL) uptake and expresses endothelial nitric oxide synthase (eNOS), plateletendothelial cell adhesion molecule-1 (PECAM-1, also known as CD 31) and VE-cadherin (CD144), which, in addition to vWf, are classical markers of endothelial cell phenotype). Moreover, HUVEC-CS cells spontaneously form capillary-like structures when grown on Matrigel. Receptors for angiotensin II (AII), bradykinin and ATP were also detected on these cells (Gifford et al. 2004). However, commercially available frozen lots of HUVECCS cells have a relatively low doubling potential - from 5 to 8 population doubling times only. Therefore, in order to establish permanent and immortalized HUVEC cells, these cells were fused with A549 cells derived from a human lung carcinoma, and formed hybrid cells referred to as EA.hy 926 cells. These cells express at least one highly differentiated function of vascular endothelium, i.e. factor VIII-related antigen, which has been maintained in these cells for more than 100 cumulative population doublings, including more than 50 passages and three cloning steps (Edgell et al. 1983). These cells were used in our earlier studies performed on PTFE irradiated with UV light continuously or in the form of microdomains (Heitz et al. 2003, Mikulíková et al. 2005).

After screening materials using cell lines, it is necessary to verify the results on primary or lowpassaged cells. These cells keep their characteristic phenotype features better than commercially available lines, e.g., they contain higher concentrations of markers 
specific for or typical for a given cell type, such as alphaactin for VSMC, vWf for endothelial cells or osteocalcin for osteoblasts (Bačáková et al. 2000a,b, Ding et al. 2006). In addition, they are more sensitive to the physical and chemical properties of the material, and thus the differences between individual tested materials are more visible. In our studies, we have often used smooth muscle cells isolated by the explantation method from the complex of the tunica intima and media of the thoracic aorta of young adult Wistar rats (Bačáková et al. 1997, 1999, 2000a, 2001a, 2002, 2003, 2007, Pařízek et al. 2009).

The highest level of material testing in vitro is achieved with the use of primocultures and low-passaged cells isolated from human patient tissues, isolated during surgery or in biopsies, but this requires ethical approval. An alternative and less complicated way is to use commercially available primocultured and low-passaged human cells purchased from specialized companies. However, these cells are expensive, available in limited quantities, of relatively short durability, and require specific cultivation conditions. Primocultured and lowpassaged human cells are therefore used mainly for verification of selected promising results and for their further development.

Progenitor and stem cells are another important and advanced cell source for testing the cell-material interaction and for constructing bioartificial blood vessels. The most commonly used are mesenchymal stem cells (MSC) derived from the bone marrow (Suzuki et al. 2010), e.g. bioptically from the crista ossis ilii. However, MSCs have proved to be less suitable for vascular tissue engineering due to their high tendency to calcification. Alternative sources of progenitor cells are human umbilical cord cells, endothelial- and VSMC-progenitor cells from peripheral blood, adipose-derived stem cells, skeletal muscle satellite cells or amniotic fluid-derived cells (for a review, see Filová et al. 2009b,c).

\section{Methods for evaluating the cell-material interaction in vitro}

It is advantageous to start investigating cellmaterial interactions with simple, standardized and reproducible tests, which are applicable for various types of material and cells. For the first tests, two-dimensional material samples of a defined size are inserted into culture dishes, usually in multiwell plates, which enable simultaneous testing of several experimental groups of samples in multiplicates. The samples are then seeded with an appropriate concentration of cells, and the changes in cell numbers in several time intervals are observed (Bačáková et al. 2000a,b, 2001a, Pařízek et al. 2009). In our earlier studies, counting cells on days 1,3 , 5 and 7 after seeding proved to be advantageous and satisfactory for constructing growth curves with three typical phases of cell growth. These phases are (1) the lag phase, when the cells attach and spread on the tested surface, and their number does not change or even decreases slightly, (2) the exponential phase, when the cells divide and more or less increase their number, and (3) the stationary phase, when the cells reach confluence, their growth is inhibited by the cell-cell and cell-material contacts, and their number does not change or decreases due to death or spontaneous detachment of living cells from the material. For cell cultivation, a period not longer than 7 days is recommended, because longer periods usually require the culture medium to be changed, and this influences the course and shape of the growth curves. In addition to cell numbers, another important criterion for evaluating the "suitability" of a material for cell growth is the cell adhesion area, i.e. the cell area projected on the material. This area is usually measured one day after seeding, i.e. when the population density is relatively low, and thus the cell spreading is minimally influenced by contacts between cells and depends more on the material properties (Engler et al. 2004, Pařízek et al. 2009, Bačáková and Švorčík 2008). The cells on the materials can be counted either directly under a microscope or after they have been detached with the use of proteolytic enzymes or calcium chelators, e.g. trypsin combined with EDTA. Native living cells can be evaluated on transparent materials, while cells on less transparent or non-transparent materials are usually studied by fluorescence methods, e. g. after staining with fluorescent dyes, such as Texas Red $\mathrm{C}_{2}$-Maleimide, which conjugates with proteins of the cell membrane and cytoplasm, and Hoechst \#33342, which visualizes the cell nucleus (Kasálková et al. 2008, 2010, Pařízek et al. 2009, Švorčík et al. 2009). It is advantageous to count the trypsinized cells at later time intervals (i.e., day 5 or 7), when the cells usually reach high population densities, overlap each other and grow in several layers (this behavior is typical for VSMCs, which form so-called "hills and valleys"). Trypsinized cells in suspension can be counted manually in a haemocytometer, e.g. a Bürker chamber, or automatically in a cell counter, e.g. a ViCELL XR Analyzer (Beckman Coulter). This apparatus enables not only simple cell counting but also an 
evaluation of the diameter and the viability of the cells, using the trypan blue-exclusion test. The cell numbers are then used not only for constructing growth curves, but also for calculating the cell population doubling time (Bačáková et al. 1997, 1999, 2000a,b, 2001a, 2002, Suzuki et al. 2010).

More advanced tests of cell-material interaction include investigations of markers of the adhesion, growth and phenotypic maturation of cells on a molecular level, i.e. on a protein or mRNA level. For protein studies, a wide range of immunocytochemical and biochemical methods can be applied, such as immunofluorescence and immunoperoxidase staining, protein electrophoresis, immunoblotting and enzyme-linked immunosorbent assay (ELISA). For mRNA studies, an advantageous technique is real-time polymerase chain reaction (real time-PCR; Kato et al. 1998, Ding et al. 2006, Nayab et al. 2007, Suzuki et al. 2010).

Molecular markers of cell adhesion include the presence, distribution, concentration and activation of various types of adhesion receptors, especially integrins, their clustering into focal adhesion plaques, their association with structural and signaling molecules, such as paxillin, talin, vinculin, focal adhesion kinase, and the assembly of an actin cytoskeleton (Bačáková et al. 2002, 2004, 2007, Bačáková and Švorčík 2008, Pařízek et al. 2009).

Molecular criteria for evaluating the proliferation activity of cells, often used in our studies, are the incorporation of bromodeoxyuridine into newly synthesized DNA, showing the S-phase fraction, i.e., the percentage of cells actually synthesizing DNA (Bačáková et al. 2001a), and the presence of the Ki-67 antigen (revealing the Growth Fraction, i.e., the percentage of cells capable of entering the mitotic cycle). The cell hypertrophy can be evaluated by measuring the cell volume and the total protein content, i.e., parameters which often increase with increasing cell spreading (Bačáková et al. 2000a, 2001b). VSMCs are prone to a specific type of hypertrophy, characterized by polyploidia, which can be revealed by counting chromosomes after arresting the cells in the metaphase, or by studies on DNA content performed by flow cytometry (Bačáková et al. 2000a, 2001b).

Other important indicators of the proper behavior of cells on artificial scaffolds are the presence and high concentration of molecules associated with cell differentiation and phenotypic maturation. In VSMCs, these markers are represented by contractile proteins alpha-actin and SM1 and SM2 isoforms of myosin, a protein of intermediate filaments desmin, muscle type of tropomyosin, T-troponin, h-caldesmon, h1-calponin and meta-vinculin (Brinck et al. 1997, Girjes et al. 2002, Hai and $\mathrm{Gu}$ 2006, Suzuki et al. 2010). Similarly as for molecules involved in cell adhesion, also for these proteins we evaluate their organization into specific structures, for example the formation of alpha-actincontaining filaments and filament bundles, and the concentration of alpha-actin per mg of protein or per cell in cell homogenates, usually by the ELISA method (Bačáková et al. 2000a,b, 2002, Filová 2009a,c, Pařizek et al. 2009).

Other important markers of cell behaviour on artificial materials are markers of cell viability and death, DNA damage, stress adaptation and immune activation. Markers of cell viability include the activity of mitochondrial enzymes, assessed by MTT, XTT and other related tests (Bačáková et al. 2002, Grausová et al. 2009), and also the activity of esterases, detected by commercially available kits (e.g. the LIVE/DEAD viability/cytotoxicity kit, Molecular Probes, Invitrogen; Grausová et al. 2009). For detecting dead cells, assays based on membrane permeability for nuclear dyes, such as ethifium homodimer-1, propidium iodide, Hoechst \#33258 and \#33342, and trypan blue can be used (Grausová et al. 2009). As a marker of DNA damage response, gamma-H2AX, i.e., a member of the histone H2A family H2AX phosphorylated at Ser139, can be detected by phosphospecific antibodies. The phosphorylation of $\mathrm{H} 2 \mathrm{AX}$ is triggered by the formation of nuclear double-strand breaks, and this is the first step in recruiting and localizing DNA repair proteins, such as p53 binding protein 1 (53BP1) (Schultz et al. 2000). Heat shock proteins (HSP), such as HSP 60,70 and 90, can be used as markers of cellular adaptation to stress, (Amberger et al. 1997, Kato et al. 1998). Long-term tolerance of the material by cells can be assessed by cultivating cells on these materials for a period of several months (Bačáková et al. 2000a).

Potential immune activation of cells in cultures on the tested materials can be estimated by the increased concentration of immunoglobulin and selectin adhesion molecules (ICAM-1, VCAM-1, ELAM-1), which bind cells of the immune system (Bačáková et al. 2000a,b, 2002). Other markers are activation of the production of interleukins (IL) and tumor necrosis factors (TNF), e.g., IL-1, IL-8 and TNF-alpha (Pešáková et al. 2007). 


\section{Conclusions}

Vascular smooth muscle cells play important roles in the physiological function of blood vessels, and also in their remodeling under pathological conditions. Nevertheless, our earlier studies showed that these cells are also a convenient model for testing materials for potential construction of bioartificial vascular replacements by tissue engineering methods. The adhesion, migration, proliferation and differentiation abilities of these cells are important factors in the search for optimal materials and modifications to them that will applicable in clinical practice. Materials for vascular replacements of a new generation should be biomimetic, i.e. actively controlling the adhesion, growth and phenotypic maturation of vascular cells, and should serve as structures promoting the regeneration of vascular tissue. For this purpose, it is necessary to investigate the physical, chemical and biological properties and modifications of materials that are promising for the construction of bioartificial vascular replacements, and to understand the molecular mechanism of the cell-material interaction. One of the most important conclusions of this review is that besides endothelial cells, used earlier for lining the luminal surface of synthetic vascular grafts, VSMCs should become an essential part of bioartificial vascular replacements. The maturation of VSMCs into contractile phenotype can be further helped by exposure of the cell-material construct to dynamic cultivation, and by appropriate composition of the cell culture medium.

\section{Conflict of Interest}

There is no conflict of interest.

\section{Acknowledgements}

This study was supported by the Grant Agency of the Czech Republic (grants No. 305/08/0108 and P108/10/1106) and the Academy of Sciences of the Czech Republic (grant No. KAN400480701). Mr. Robin Healey (Czech Technical University, Prague) is gratefully acknowledged for his language revision of the manuscript.

\section{References}

ABRAHAM LC, ZUENA E, PEREZ-RAMIREZ B, KAPLAN DL: Guide to collagen characterization for biomaterial studies. J Biomed Mater Res B Appl Biomater 87: 264-285, 2008.

AMBERGER A, MACZEK C, JURGENS G, MICHAELIS D, SCHETT G, TRIEB K, EBERL T, JINDAL S, XU QB, WICK G: Co-expression of ICAM-1, VCAM-1, ELAM-1 and Hsp60 in human arterial and venous endothelial cells in response to cytokines and oxidized low-density lipoproteins. Cell Stress Chaperon 2: 94-103, 1997.

BAČÁKOVÁ-ŘEǨÁBKOVÁ L: Importance of cultivation of smooth muscle cells for understanding of the physiology and pathophysiology of the vascular wall. (in Czech) Cs fyziol 39: 412-427, 1990.

BAČÁKOVÁ L, ŠVORČÍK V, RYBKA V, MÍČEK I, HNATOWICZ V, LISÁ V, KOCOUREK F: Adhesion and proliferation of cultured human vascular smooth muscle cells on polystyrene implanted with $\mathrm{N}^{+}, \mathrm{F}^{+}$and $\mathrm{Ar}^{+}$ ions. Biomaterials 17: 1121-1126, 1996.

BAČÁKOVÁ L, WILHELM J, HERGET J, NOVOTNÁ J, ECKHARDT A: Oxidized collagen stimulates proliferation of vascular smooth muscle cells. Exp Mol Pathol 64: 185-194, 1997.

BAČÁKOVÁ L, WILHELM J, HERGET J, NOVOTNÁ J: Influence of macrophages and macrophage-modified collagen I on the adhesion and proliferation of vascular smooth muscle cells in culture. Physiol Res 48: 341351, 1999.

BAČÁKOVÁ L, MAREŠ V, BOTTONE MG, PELLICCIARI C, LISÁ V, ŠVORČÍK V: Fluorine ion-implanted polystyrene improves growth and viability of vascular smooth muscle cells in culture. J Biomed Mater Res 49: 369-379, 2000a.

BAČÁKOVÁ L, MAREŠ V, LISÁ V, ŠVORČÍK V: Molecular mechanisms of improved adhesion and growth of an endothelial cell line cultured on polystyrene implanted with fluorine ions. Biomaterials 21: 1173-1179, $2000 \mathrm{~b}$.

BAČÁKOVÁ L, WALACHOVÁ K, ŠVORČÍK V, HNATOWICZ V: Adhesion and proliferation of rat vascular smooth muscle cells on polyethylene implanted with $\mathrm{O}^{+}$and $\mathrm{C}^{+}$ions. J Biomater Sci-Polym Ed 12: 817-834, 2001a. 
BAČÁKOVÁ L, PELLICCIARI C, BOTTONE MG, LISÁ V, MAREŠ V: A sex-related difference in the hypertrophic versus hyperplastic response of vascular smooth muscle cells to repeated passaging in culture. Histol Histopathol 16: 675-684, 2001b.

BAČÁKOVÁ L, LISÁ V, KUBÍNOVÁ L, WILHELM J, NOVOTNÁ J, ECKHARDT A, HERGET J: Ultraviolet lightirradiated collagen III modulates expression of cytoskeletal and surface adhesion molecules in rat aortic smooth muscle cells in vitro. Virchows Arch 440: 50-62, 2002.

BAČÁKOVÁ L, LAPČÍKOVÁ M, KUBIES D, RYPÁČEK F: Adhesion and growth of rat aortic smooth muscle cells on lactide-based polymers. Adv Exp Med Biol 534: 179-189, 2003.

BAČÁKOVÁ L, FILOVÁ E, RYPÁČEK F, ŠVORČÍK V, STARÝ V: Cell adhesion on artificial materials for tissue engineering. Physiol Res $\mathbf{5 3}$ (Suppl 1): S35-S45, 2004.

BAČÁKOVÁ L, FILOVÁ E, KUBIES D, MACHOVÁ L, PROKŠ V, MALINOVÁ V, LISÁ V, RYPÁČEK F: Adhesion and growth of vascular smooth muscle cells in cultures on bioactive RGD peptide-carrying polylactides. J Mater Sci Mater Med 18: 1317-1323, 2007.

BAČÁKOVÁ L, ŠVORČÍK V: Cell colonization control by physical and chemical modification of materials. In: Cell Growth Processes: New Research. D KIMURA (ed), Nova Science Publishers, Inc., Hauppauge, NY, USA, 2008, pp 5-56.

BAČÁKOVÁ L, FILOVÁ E, GRAUSOVÁ L, VANDROVCOVÁ M, PAŘÍZEK M, NOVOTNÁ K, ŠVORČÍK V, VACÍK J, RYPÁČEK F, KROMKA A, HEITZ J, SHARD A: Micro- and nanopatterned surfaces for guided adhesion, growth and phenotypic maturation of cells. Engineering of Biomaterials 89-91: 18-21, 2009.

BANDIERA A, TAGLIENTI A, MICALI F, PANI B, TAMARO M, CRESCENZI V, MANZINI G: Expression and characterization of human-elastin-repeat-based temperature-responsive protein polymers for biotechnological purposes. Biotechnol Appl Biochem 42: 247-256, 2005.

BARNES JL, TORRES ES, MITCHELL RJ, PETERS JH: Expression of alternatively spliced fibronectin variants during remodeling in proliferative glomerulonephritis. Am J Pathol 147: 1361-1371, 1995.

BETTINGER CJ, BRUGGEMAN JP, MISRA A, BORENSTEIN JT, LANGER R: Biocompatibility of biodegradable semiconducting melanin films for nerve tissue engineering. Biomaterials 30: 3050-3057, 2009.

BRINCK U, MIRZAIE M, KORABIOWSKA M, MEYER T: Expression rate of vinculin isoforms in human aortocoronary saphenous vein grafts. Since the cytoskeletal protein meta-vinculin is present exclusively in contractile smooth muscle cells 1. Int J Cardiol 59: 125-132, 1997.

BRYNDA E, PACHERNÍK J, HOUSKA M, PIENTKA Z, DVOŘÁK P: Surface immobilized protein multilayers for cell seeding. Langmuir 21: 7877-7883, 2005.

CAMPBELL GR, CAMPBELL JH: Development of the vessel wall: overview. In: The Vascular Smooth Muscle Cell. Molecular and Biological Response to the Extracelular Matrix. SCHWARTZ SM, MECHAM RP (eds), Academic Press, San Diego, London, 1995, pp 1-15.

CHIANG HY, KORSHUNOV VA, SEROUR A, SHI F, SOTTILE J: Fibronectin is an important regulator of flowinduced vascular remodeling. Arterioscler Thromb Vasc Biol 29: 1074-1079, 2009.

CHLUPÁČ J, FILOVÁ E, RIEDEL T, BRYNDA E, REMY-ZOLGHADRI M, BAREILLE R, FERNANDEZ P, DACULSI R, BORDENAVE L, BAČÁKOVÁ L: Human endothelium on vascular prostheses modified by extracellular matrix proteins in a flow experiment. Engineering of Biomaterials 58-60: 10-13, 2006.

CHLUPÁČ J, FILOVÁ E, RIEDEL T, BRYNDA E, PAMULA E, LISÁ V, BAČÁKOVÁ L: Endothelial cells on PET vascular prostheses impregnated with polyester-based copolymers and coated with cell-adhesive protein assemblies. Engineering of Biomaterials 81-84: 108-111, 2008.

CHLUPÁČ J, FILOVÁ E, BAČÁKOVÁ L: Blood vessel replacement: 50 years of development and tissue engineering paradigms in vascular surgery. Physiol Res 58 (Suppl 2): S119-S139, 2009.

COSTA-SILVA B, DA COSTA MC, MELO FR, NEVES CM, ALVAREZ-SILVA M, CALLONI GW, TRENTIN AG: Fibronectin promotes differentiation of neural crest progenitors endowed with smooth muscle cell potential. Exp Cell Res 315: 955-967, 2009.

CULLIS CF, HIRSCHLER MM: The significance of thermoanalytical measurements in the assessment of polymer flammability. Polymer 24: 834-840, 1983. 
DING HT, WANG CG, ZHANG TL, WANG K: Fibronectin enhances in vitro vascular calcification by promoting osteoblastic differentiation of vascular smooth muscle cells via ERK pathway. J Cell Biochem 99: 1343-1352, 2006.

DUFOURCQ P, COUFFINHAL T, ALZIEU P, DARET D, MOREAU C, DUPLÀA C, BONNET J: Vitronectin is upregulated after vascular injury and vitronectin blockade prevents neointima formation. Cardiovasc Res 53: 952-962, 2002.

DUCHÁČEK V: Polymers - Production, Properties, Processing, Application. (in Czech) ICH, Prague, 2006.

EDGELL CJ, MCDONALD CC, GRAHAM JB: Permanent cell line expressing human factor VIII-related antigen established by hybridization. Proc Natl Acad Sci USA 80: 3734-3737, 1983.

ENGLER A, BAČÁKOVÁ L, NEWMAN C, HATEGAN A, GRIFFIN M, DISCHER D: Substrate compliance versus ligand density in cell on gel responses. Biophys $J$ 86: 617-628, 2004.

FAGER G, HANSSON GK, GOWN AM, LARSON DM, SKALLI O, BONDJERS G: Human arterial smooth muscle cells in culture: inverse relationship between proliferation and expression of contractile proteins. In Vitro Cell Dev Biol 25: 511-520, 1989.

FILOVÁ E, BRYNDA E, RIEDEL T, BAČÁKOVÁ L, CHLUPÁČ J, LISÁ V, HOUSKA M, DYR JE: Vascular endothelial cells on two- and three-dimensional fibrin assemblies for biomaterial coatings. J Biomed Mater Res A 90: 55-69, 2009a.

FILOVÁ E, STRAKA F, MIŘEJOVSKÝ T, MAŠÍN J, BAČÁKOVÁ L: Tissue-engineered heart valves. Physiol Res 58 (Suppl 2): S141-S158, 2009b.

FILOVÁ E, BULlETT NA, BAČÁKOVÁ L, GRAUSOVÁ L, HAYCOCK JW, HLUČILOVÁ J, KLÍMA J, SHARD A: Regionally-selective cell colonization of micropatterned surfaces prepared by plasma polymerisation of acrylic acid and 1,7- octadiene. Physiol Res 58: 669-684, 2009c.

FINK D (ed): Fundamentals of Ion-Irradiated Polymers. Springer Series in Materials Science vol. 63: 2004.

GIFFORD SM, GRUMMER MA, PIERRE SA, AUSTIN JL, ZHENG J, BIRD IM: Functional characterization of HUVEC-CS: $\mathrm{Ca}^{2+}$ signaling, ERK $1 / 2$ activation, mitogenesis and vasodilator production. J Endocrinol 182: 485-499, 2004.

GIRJES AA, KERIAKOUS D, COCKERILL GW, HAYWARD IP, CAMPBELL GR, CAMPBELL JH: Cloning of a differentially expressed tropomyosin isoform from cultured rabbit aortic smooth muscle cells. Int J Biochem Cell Biol 34: 505-515, 2002.

GLUKHOVA MA, KOTELIANSKY VE: Integrins, cytoskeletal and extracellular matrix proteins in developing smooth muscle cells of human aorta. In: The Vascular Smooth Muscle Cell. Molecular and Biological Response to the Extracelular Matrix. SCHWARTZ SM, MECHAM RP (eds), Academic Press, San Diego, London, 1995, pp 37-79.

GOBIN AS, WEST JL: Val-ala-pro-gly, an elastin-derived non-integrin ligand: smooth muscle cell adhesion and specificity. J Biomed Mater Res A 67: 255-259, 2003.

GRAUSOVÁ L, BAČÁKOVÁ L, KROMKA A, POTOCKÝ Š, VANĚČEK M, NESLÁDEK M, LISÁ V: Nanodiamond as a promising material for bone tissue engineering. J Nanosci Nanotechnol 9: 3524-3534, 2009.

GRAVES DC, YABLONKA-REUVENI Z: Vascular smooth muscle cells spontaneously adopt a skeletal muscle phenotype: a unique Myf5(-)/MyoD(+) myogenic program. J Histochem Cytochem 48: 1173-1193, 2000.

GREISLER HP, TATTERSALL CW, KLOSAK JJ, CABUSAO EA, GARFIELD JD, KIM DU: Partially bioresorbable vascular grafts in dogs. Surgery 110: 645-654, 1991.

GUIDOIN R, MAUREL S, CHAKFÉ N, HOW T, ZHANG Z, THERRIEN M, FORMICHI M, GOSSELIN C: Expanded polytetrafluoroethylene arterial prostheses in humans: chemical analysis of 79 explanted specimens. Biomaterials 14: 694-704, 1993.

HAI CM, GU Z: Caldesmon phosphorylation in actin cytoskeletal remodeling. Eur J Cell Biol 85: 305-309, 2006.

HAMEED T, HUSSEIN IA: Effect of short chain branching of LDPE on its miscibility with linear HDPE. Macromol Mater Eng 289: 198-203, 2004.

HEDIN U, THYBERG J: Plasma fibronectin promotes modulation of arterial smooth-muscle cells from contractile to synthetic phenotype. Differentiation 33: 239-246, 1987. 
HEITZ J, ŠVORČÍK V, BAČÁKOVÁ L, ROCKOVÁ K, RATAJOVÁ E, GUMPENBERGER T, BAUERLE D, DVOŘÁNKOVÁ B, KAHR H, GRAZ I, ROMANIN C: Cell adhesion on polytetrafluoroethylene modified by UV-irradiation in an ammonia atmosphere. J Biomed Mater Res A 67: 130-137, 2003.

JEONG SI, JUN ID, CHOI MJ, NHO YC, LEE YM, SHIN H: Development of electroactive and elastic nanofibers that contain polyaniline and poly(L-lactide-co-epsilon-caprolactone) for the control of cell adhesion. Macromol Biosci 7/8: 627-637, 2008.

KAKISIS JD, LIAPIS CD, BREUER C, SUMPIO BE: Links artificial blood vessel: the Holy Grail of peripheral vascular surgery. Vasc Surg 41: 349-354, 2005.

KARNIK SK, BROOKE BS, BAYES-GENIS A, SORENSEN L, WYTHE JD, SCHWARTZ RS, KEATING MT, LI DY: A critical role for elastin signaling in vascular morphogenesis and disease. Development 130: 411-423, 2003.

KASÁLKOVÁ N, KOLÁŘOVÁ K, BAČÁKOVÁ L, PAŘÍZEK M, ŠVORČÍK V: Cell adhesion and proliferation on modified PE. Mater Sci Forum 567-568: 269-272, 2008.

KASÁLKOVÁ N, MAKAJOVÁ Z, PAŘÍZEK M, SLEPIČKA P, KOLÁŘOVÁ K, BAČÁKOVÁ L, HNATOWICZ V, ŠVORČ́́K V: Cell adhesion and proliferation on plasma-treated and poly(ethylene glycol)-grafted polyethylene. J Adhes Sci Technol 24: 743-754, 2010.

KATO S, AKAGI T, SUGIMURA K, KISHIDA A, AKASHI M: Evaluation of biological responses to polymeric biomaterials by RT-PCR analysis III: study of HSP 70, 90 and 47 mRNA expression. Biomaterials 19: 821827, 1998.

KUBOVÁ O, ŠVORČÍK V, HEITZ J, MORITZ S, ROMANIN C, MATĚJKA P, MACKOVÁ A: Characterization and cytocompatibility of carbon layers prepared by photo-induced chemical vapor deposition. Thin Solid Films 515: 6765-6772, 2007.

LIU X, LIM JY, DONAHUE HJ, DHURJATI R, MASTRO AM, VOGLER EA: Influence of substratum surface chemistry/energy and topography on the human fetal osteoblastic cell line hFOB 1.19: Phenotypic and genotypic responses observed in vitro. Biomaterials 28: 4535-4550, 2007.

MACKOVÁ A, ŠVORČÍK V, STRÝHAL Z, PAVLÍK J: RBS and AFM study of Ag and Au diffusion into PET influenced by plasma treatment. Surf Interf Anal 38: 335, 2006.

MAROIS Y, CHAKFÉ N, GUIDOIN R, DUHAMEL RC, ROY R, MAROIS M, KING MW, DOUVILLE Y: An albumin-coated polyester arterial graft: in vivo assessment of biocompatibility and healing characteristics. Biomaterials 17: 3-14, 1996.

MAXOVÁ H, BAČÁKOVÁ L, LISÁ V, NOVOTNÁ J, TOMÁŠOVÁ H, VÍZEK M, HERGET J: Production of proteolytic enzymes in mast cells, fibroblasts, vascular smooth muscle and endothelial cells cultivated under normoxic or hypoxic conditions. Physiol Res 59:711-719. 2010.

MIHARDJA SS, SIEVERS RE, LEE RJ: The effect of polypyrrole on arteriogenesis in an acute rat infarct model. Biomaterials 29: 4205-4210, 2008.

MIKULÍKOVÁ R, MORITZ S, GUMPENBERGER T, OLBŘICH M, ROMANIN C, BAČÁKOVÁ L, ŠVORČÍK V, HEITZ J: Cell microarrays on photochemically modified polytetrafluoroethylene. Biomaterials 26/27: 5572$5580,2005$.

MILLER DC, HABERSTROH KM, WEBSTER TJ: PLGA nanometer surface features manipulate fibronectin interactions for improved vascular cell adhesion. J Biomed Mater Res A 81: 678-684, 2007.

NAYAB SN, JONES FH, OLSEN I: Effects of calcium ion-implantation of titanium on bone cell function in vitro. J Biomed Mater Res A 83: 296-302, 2007.

NEČAS O, SVOBODA A, HEJTMÁNEK M, JANISCH R, ČERVINKA M, LENHART K, KOLÁŘ Z: General Biology. (in Czech) H \& H, Prague, 2000, pp 257-261 and 276-278.

OCHSENHIRT SE, KOKKOLI E, MCCARTHY JB, TIRRELL M: Effect of RGD secondary structure and the synergy site PHSRN on cell adhesion, spreading and specific integrin engagement. Biomaterials 27: 3863-3874, 2006.

ORR AW, HASTINGS NE, BLACKMAN BR, WAMHOFF BR: Complex regulation and function of the inflammatory smooth muscle cell phenotype in atherosclerosis. J Vasc Res 47: 168-180, 2009. 
PAŘÍZEK M, KASÁLKOVÁ N, BAČÁKOVÁ L, SLEPIČKA P, LISÁ V, BLAŽKOVÁ M, ŠVORČÍK V: Improved adhesion, growth and maturation of vascular smooth muscle cells on polyethylene grafted with bioactive molecules and carbon particles. Int J Mol Sci 10: 4352-4374, 2009.

PEŠÁKOVÁ V, KUBIES D, HULEJOVÁ H, HIMMLOVÁ L: The influence of implant surface properties on cell adhesion and proliferation. J Mater Sci Mater Med 18: 465-473, 2007.

ROHATGI A, OWENS AW, KHERA A, AYERS CR, BANKS K, DAS SR, BERRY JD, MCGUIRE DK, DE LEMOS JA: Differential associations between soluble cellular adhesion molecules and atherosclerosis in the Dallas Heart Study: a distinct role for soluble endothelial cell-selective adhesion molecule. Arterioscler Thromb Vasc Biol 29: 1684-1690, 2009.

ROY J, TRAN PK, RELIGA P, KAZI M, HENDERSON B, LUNDMARK K, HEDIN U: Fibronectin promotes cell cycle entry in smooth muscle cells in primary culture. Exp Cell Res 15: 169-177, 2002.

SCHULTZ LB, CHEHAB NH, MALIKZAY A, HALAZONETIS TD: p53 binding protein 1 (53BP1) is an early participant in the cellular response to DNA double-strand breaks. $J$ Cell Biol 151: 1381-1390, 2000.

SHIMIZU N, YAMAMOTO K, OBI S, KUMAGAYA S, MASUMURA T, SHIMANO Y, NARUSE K, YAMASHITA JK, IGARASHI T, ANDO J: Cyclic strain induces mouse embryonic stem cell differentiation into vascular smooth muscle cells by activating PDGF receptor beta. $J$ Appl Physiol 104: 766-772, 2008.

SUZUKI S, NARITA Y, YAMAWAKI A, MURASE Y, SATAKE M, MUTSUGA M, OKAMOTO H, KAGAMI H, UEDA M, UEDA Y: Effects of extracellular matrix on differentiation of human bone marrow-derived mesenchymal stem cells into smooth muscle cell lineage: utility for cardiovascular tissue engineering. Cells Tissues Organs 191: 269-280, 2010.

ŠVORČÍK V, RYBKA V, ENDRŠT R, HNATOWICZ V, KVÍTEK J: Ion implantation into polyethylene. J Electrochem Soc 140: 549, 1993.

ŠVORČÍK V, RYBKA V, HNATOWICZ V, BAČÁKOVÁ L, LISÁ V, KOCOUREK F: Surface properties and biocompatibility of ion implanted polymers. J Mater Chem 5: 27-30, 1995.

ŠVORČÍK V, KOLÁŘOVÁ K, SLEPIČKA P, MACKOVÁ A, NOVOTNÁ M, HNATOWICZ V: Modification of surface properties of high and low density PE by Ar plasma discharge. Polym Degr Stab 91, 1219-1225, 2006.

ŠVORČÍK V, HNATOWICZ V: Properties of polymers modified by plasma discharge and ion beam, In: Polymer Degradation and Stability Research Developments. LB ALBERTOV (ed), Nova Science Publishers, New York, 2007, pp 171-216.

ŠVORČÍK V, KASÁLKOVÁ N, SLEPIČKA P, ZÁRUBA K, BAČÁKOVÁ L, PAŘÍZEK M, LISÁ V, RUML T, GBELCOVÁ H, RIMPELOVÁ S, MACKOVÁ A: Cytocompatibility of $\mathrm{Ar}^{+}$plasma-treated and $\mathrm{Au}$ nanoparticle-grafted PE. Nucl Instr Meth B 267: 1904-1910, 2009.

VAN BILSEN PH, KRENNING G, BILLY D, DUVAL JL, HUURDEMAN-VINCENT J, VAN LUYN MJ: Heparin coating of poly(ethylene terephthalate) decreases hydrophobicity, monocyte/leukocyte interaction and tissue interaction. Colloids Surf B Biointerfaces 67: 46-53, 2008.

WALACHOVÁ K, ŠVORČÍK V, BAČÁKOVÁ L, HNATOWICZ V: Smooth muscle cell interaction with modified polyethylene. Biomaterials 23: 2989-2996, 2002.

WANG H, RIHA GM, YAN S, LI M, CHAI H, YANG H, YAO Q, CHEN C: Shear stress induces endothelial differentiation from a murine embryonic mesenchymal progenitor cell line. Arterioscler Thromb Vasc Biol 25: 1817-1823, 2005.

XUE L, GREISLER HP: Biomaterials in the development and future of vascular grafts. J Vasc Surg 37: 472-478, 2003.

YOU Q, WANG F, DUAN L, DU X, XIAO M, SHEN Z: Construction of small-caliber, polydioxanone cyclohexanone vascular stents. Cell Biochem Biophys 57: 35-43, 2010.

ZAIDEL-BAR R, MILO R, KAM Z, GEIGER B: A paxillin tyrosine phosphorylation switch regulates the assembly and form of cell-matrix adhesions. $J$ Cell Sci 120: 137-148, 2007. 